\section{CRITICAL MEDICAL AND SURGICAL NURSING JOURNAL \\ Vol. 8, No. 2, October 2019}

Journal Homepage: https://e-journal.unair.ac.id/CMSNJ

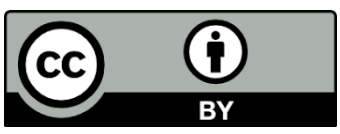

This is an Open Access article distributed under the terms of the Creative Commons Attribution 4.0 International License

\title{
Analisis Faktor yang Berhubungan dengan Kejadian Ulkus Diabetik pada Pasien DM Tipe 2 di Poli Penyakit Dalam RSUD Umbu Rara Meha Waingapu
}

\author{
Retno Indarwati, Praba Dian R, Yunita Veronika Sidhu \\ Fakultas Keperawatan, Universitas Airlangga, Surabaya, Indonesia
}

\section{ARTICLE HISTORY \\ Diterima: 12 Februari 2020 \\ Disetujui: 30 Juni 2020}

\section{KEYWORDS}

diabetes mellitus ulcer, blood sugar levels, foot care, stress level, diabetes

\section{CORRESPONDING AUTHOR}

Retno Indarwati retno-i@fkp.unair.ac.id Fakultas Keperawatan, Universitas Airlangga

\begin{abstract}
Introduction: The incidence of Diabetic Foot Ulcer (DFU) is currently still quite high resulting in a decrease in the quality of life and increase dependence on family and health services. But until now the factors that cause DFU are still not known with certainty. This study aimed to analyze the relationship of host factors with the incidence of foot ulcers in type 2 DM patients.

Method: The method used in this study was cross sectional, involving 115 patients with Type 2 diabetes who did not have other comorbidities and mental disorders. The variables studied were blood sugar levels, foot care and stress levels. Measuring instruments used were the Nottingham Assessment of Functional Footcare questionnaire and the Diabetes Distress Scale questionnaire. The collected data were analyzed using the Spearman Rho test with a significance level of 0.05 .

Results: Most respondents had high levels of stress, poor foot care and blood sugar levels $<200 \mathrm{md} / \mathrm{dl}$. Bivariate test results showed that the host factors in this study were related to the incidence of DM ulcers including foot care $(p=0.003: r=0.276)$, stress level $(p=0.049$ : $r=0.230)$, blood sugar control $(p=0.013: r=0.184)$ which means that overall the variables are related to DFU events. Discussion: Overall the variables have a positive relationship. Good foot care will reduce the risk of DM ulcers. Stress levels and high blood sugar levels will increase the risk of DM ulcers.

Conclusion: Factors of blood sugar levels, stress levels, and foot care can influence the incidence of DM ulcers so that interventions are needed that can improve the behavior of foot care, blood sugar levels and stress management.
\end{abstract}

Indarwati, R., Rahmawati, P. D., \& Sidhu, Y. V. (2019). Analisis Faktor yang Berhubungan dengan Kejadian Ulkus Diabetik Pada Pasien Diabetes Tipe 2 di Poli Penyakit Dalam RSUD Umbu Rara Meha Waingapu. Crit. Méd. Surgical. Nurs. J, 8(2), 96-104.

\section{INTRODUCTION}

Kejadian Diabetic Foot Ulcer (DFU) saat ini masih cukup tinggi dan dialami oleh 85\% pasien dengan diabetes melitus (DM). Satu dari setiap 20 pasien DM rawat inap menderita DFU menurut tinjauan sistematis pasien dengan diabetes. Anggota tubuh bagian bawah hilang karena diabetes setiap 20 detik (Yazdanpanah et al., 2018). Adanya DFU mengakibatkan adanya penurunan kualitas hidup dan meningkatkan ketergantungan terhadap keluarga dan pelayanan kesehatan. Faktor risiko utama DFU adalah neuropati diabetik, vaskular penyakit, kelainan bentuk kaki dan penurunan resistensi terhadap infeksi. Akhir dari perjalanan penyakit ulkus kaki pada pasien diabetes melitus adalah amputasi yang memiliki banyak efek pada kualitas hidup pasien diabetes. Tingkat kelangsungan hidup untuk pasien yang menjalani amputasi adalah sekitar 50\% setelah tiga tahun. Risiko amputasi pada pasien dengan diabetes adalah 15 kali lebih besar dari pada pasien tanpa diabetes (Yazdanpanah et al., 2018). Namun sampai saat ini faktor yang 
menyebabkan DFU masih belum diketahui secara pasti.

World Health Organization menyatakan bahwa prevalensi DM di seluruh dunia diperkirakan sebesar 9\%. Pada tahun 2030 diperkirakan DM menempati urutan ke-7 penyebab kematian di dunia (WHO, 2014). International Diabetes Federation (IDF) memprediksi adanya kenaikan jumlah penyandang DM di Indonesia dari 9,1 juta pada tahun 2014 menjadi 14,1 juta pada tahun 2035. Penderita DM di Indonesia pada usia $\geq 15$ tahun sebesar $6,9 \%$ diperkirakan jumlah absolutnya sebesar 12 juta jiwa. Hampir 50\% penderita diabetes mengalami ulkus kaki diabetik dengan angka kematian 8\%-35\% dan 15\%-30\% diantaranya mengalami amputasi (Riskesdas, 2018). Berdasarkan data RSUD Umbu Rara Meha Waingapu ditemukan kasus DM meningkat dalam 3 tahun terakhir. Tahun 2016 terdapat 119 kasus, 2017 terdapat 255 kasus dan 2018 terdapat 806 kasus. Peningkatan kasus DM diikuti dengan peningkatan komplikasi DM yaitu DFU. Kasus DFU meningkat setiap tahun, pada tahun 2016 terdapat 38 kasus, 2017 terdapat 45 kasus, dan 2018 terdapat 57 kasus.

Berdasarkan hasil wawancara ditemukan ketidakpatuhan dalam pengobatan,kebiasaan masyarakat waingapu yang menderita penyakit DM lebih sering mengonsumsi obat-obatan herbal seperti minum rebusan daun sirsak tanpa mengontrol kadar gula darah, tidak patuh diit karena mereka berasumsi bahwa dengan mengonsumsi obat-obatan herbal maka kadar gula darah akan turun dengan sendirinya sehingga boleh mengonsumsi makanan jenis apa saja tanpa melakukan pantangan.Tidak melakukan perawatan kaki,dalam hal ini yang sering dilakukan masyarakat disana tidak menggunakan alas kaki,kuku kaki dibiarkan panjang dan tidak melakukan olahraga.

Pada awal perjalanan penyakit DM, individu tidak menyadarinya, hal ini disebabkan tidak adanya gejala tetapi baru dirasakan setelah terjadi komplikasi lanjut pada organ tubuh. Pengendalian kadar gula darah yang buruk atau fluktuatif yang berkepanjangan akan mengakibatkan kerusakan dinding pembuluh darah. Hal ini menyebabkan inflamasi pada endotel pembuluh darah yang berakibat pada peningkatan progresivitas pembentukan plak ateroma, sehingga timbul penyempitan progresif lumen vaskuler dan mengganggu aliran darah ke jaringan perifer. Tingginya kadar glukosa darah akan meningkatkan viskositas darah sehingga aliran darah ke jaringan akan melambat (Silbernagl \& Lang, 2017). Viskositas darah yang meningkat mengakibatkan adanya gangguan aliran darah ke perifer sehingga seringkali timbul gangguan kaki meliputi ulkus, infeksi, ganggren dan amputasi. Gangguan pada kaki penderita DM merupakan sumber utama morbiditas, penyebab lamanya rawat inap di rumah sakit, dan meningkatnya biaya yang harus dikeluarkan oleh penderita DM (Boulton, 2019).

Ulkus kaki berawal dari hal kecil tetapi dapat mengakibatkan amputasi. Penderita DM akibat ulkus mengalami amputasi sebesar 85\% dalam jangka waktu 5 tahun (Sieggreen, 2016). Dampak amputasi ini akan membuat seseorang menjadi depresi, cemas, ada reaksi penolakan, berduka bahkan perasaan ingin bunuh diri (National Institute for Health and Clinical Excellence/ NHS, 2012). Untuk itu perlunya pengelolaan yang baik terhadap ulkus kaki. Tahap awal yang diperlukan dalam proses pengelolaan adalah pengkajian kaki dilakukan untuk mendapatkan informasi dengan anamnese dan melakukan pemeriksaan untuk menentukan etiologi dan faktor risiko ulkus kaki DM (Delmas, 2016). Esensi dari pengkajian ini untuk mencegah ulkus kaki atau ulkus kaki berulang, untuk itu perlunya mengetahui faktor risiko ulkus atau ulkus kaki berulang.

Berdasarkan penelitian Almoutaz, Ahmed, Algamdi, Algurashi, \& Abdulelah (2014) faktor risiko yang mempengaruhi kejadian ulkus kaki meliputi, 
Tabel 1 Karateristik Demografi Responden (n=115)

\begin{tabular}{llcc}
\hline $\begin{array}{c}\text { Karakteristik } \\
\text { Demografi } \\
\text { Responden }\end{array}$ & \multicolumn{1}{c}{ Kategori } & n & \% \\
\hline Usia & 26-35 Tahun & 10 & 8.7 \\
& 36-45 Tahun & 35 & 30.4 \\
Jenis Kelamin & L45 Tahun & 70 & 60.9 \\
& Perempuan & 44 & 38.3 \\
Pendidikan & Pendidikan & 17 & 61.7 \\
& Dasar & 14.8 \\
& Pendidikan & 71 & 61.7 \\
& Menengah & & \\
Tingkat Stress & Pendidikan & 27 & 23.5 \\
& Tinggi & & \\
Tinggi & 93 & 80.9 \\
Kadar gula & Sedang & 11 & 9.6 \\
darah & Rendah & 11 & 9.6 \\
Perawatan kaki & <200 & 91 & 79.1 \\
& $>200$ & 24 & 20.9 \\
Kejadian Ulkus & Buruk & 109 & 94.8 \\
DM & Tidak & 6 & 5.2 \\
Grade Ulkus & Ya & 81 & 70.4 \\
& Grade 1 & 34 & 29.6 \\
& Grade 2 & 30 & 88 \\
& & 4 & 12
\end{tabular}

laki-laki, perokok, kadar glukosa darah yang jelek, gangguan penglihatan atau diabetik retinopati, polineuropati (neuropati sensorik, otonom, motorik), trauma kaki, ulkus sebelumnya, dan kurangnya latihan. Faktor yang dominan berhubungan dengan kejadian DFU kontrol glikemik yang buruk. Menurut Mohammed et al., (2016) faktor lain yang berpengaruh pada kejadian DFU adalah lamanya menderita DM. Pada penelitian Mohammed et al., (2016) menemukan bahwa orang dengan DM lebih dari 10 tahun lebih berisiko 1.5 kali terkena DFU dibanding yang lain. Faktor pendidikan juga ditemukan berpengaruh pada kejadian DFU. Orang dengan DM yang berpendidikan rendah lebih rentan terkena DFU dibanding orang berpendidikan lebih tinggi.

Iversen et al., (2015) dalam penelitiannya yang melakukan follow up selama 11 tahun pada pasien DM menyebutkan bahwa selain masalah fisik, masalah psikologis pasien dengan DM juga berhubungan dengan kejadian DFU. Pasien DM yang mengalami depresi berisiko 3.09 kali lebih rentan mengalami DFU dibanding yang tidak depresi dengan pengukuran HADS-D. Teori John
Gordon mengemukakan bahwa timbulnya suatu penyakit sangat dipengaruhi oleh tiga faktor yaitu bibit penyakit (Agent), pejamu (Host), dan lingkungan (Environment). Pada kejadian ulkus diabetikum dapat diketahui bahwa faktor host yaitu pengendalian gula darah, tingkat stress, dan perawatan kaki. Faktor agent yang dapat diketahui adalah adanya bakteri atau virus penyebab infeksi pada kaki. Sedangkan pada faktor lingkungan yang dapat diketahui adalah faktor tempat tinggal. Berdasarkan latar belakang masalah tersebut peneliti bermaksud melakukan penelitian mengenai analisis faktor yang berhubungan dengan kejadian ulkus diabetikum pada pasien DM tipe 2. Tujuan penelitian ini adalah menganalisis hubungan faktor host dengan kejadian ulkus kaki pada pasien DM tipe 2.

\section{METHOD}

Kelayakan Metode yang digunakan dalam penelitian ini adalah cross sectional dengan mengikutsertakan 115 pasien dengan DM Tipe 2 yang tidak memiliki penyakit penyerta lain dan gangguan jiwa. Variabel yang diteliti adalah kadar gula darah, perawatan kaki dan tingkat stres. Alat ukur yang digunakan adalah kuesioner Nottingham Assesment of Functional Footcare dan kuesioner Diabetes Distres Scale. Data yang terkumpul dianalisis dengan menggunakan uji spearman rho dengan derajat kemaknaan 0.05. Uji etik telah dilakukan di Fakultas Keperawatan Universitas Airlangga dengan no.1829-KEPK.

\section{RESULT}

Berdasarkan tabel 1 dapat dilihat bahwa usia terbanyak adalah $>45$ tahun dengan jumlah 70 responden atau $60.9 \%$ sehingga melebihi setengah dari total responden yang ada. Berdasarkan jenis kelamin ditemukan jumlah terbanyak adalah perempuan dengan total 71 responden atau $67.1 \%$. Berdasarkan pendidikan jumlah terbanyak adalah pendidikan menengah sebanyak 71 responden atau 67.1\% yang terdiri dari SMP dan SMA/SMK. Sebanyak 93 responden memiliki tingkat stress 
rendah atau 80.9\%. pengendalian gula darah $<200$ $\mathrm{mg} / \mathrm{dl}$ dirasakan oleh 90 responden atau 79.1\%. perawatan kaki yang dijalani responden terbanyak adalah baik dengan jumlah 109 responden atau 94.8\%. Berdasarkan kejadian ulkus ditemukan 81 responden tidak mengalami ulkus atau $70.4 \%$ dari total responden.

Berdasarkan tabel 2 dapat dilihat pada kategori usia $>45$ tahun yang tidak terjadi ulkus DM sebanyak 49 responden dan 21 responden mengalami ulkus DM.Pada kategori jenis kelamin ditemuka kejadian ulkus DM Paling banyak adalah perempuan dengan jumlah 21 responden. Berdasarkan pendidikan ditemukan pendidikan menengah merupakan responden dengan kejadian ulkus DM terbanyak dengan jumlah 17 responden. Berdasarkan table 3 pada kategori tingkat stress ditemukan jumlah kejadian ulkus DM terbanyak ada pada tingkat stress tinggi dengan jumlah 23 responden.Pada kategori kadar gula darah kejadian ulkus DM terbanyak pada kadar gula darah < 200 sebanyak 22 responden.Pada kategori perawatan kaki kejadian ulkus terbanyak ada pada kategori perawatan kaki yang buruk sebanyak 29 responden. Berdasarkan tabel 4 yang merupakan hasil uji bivariat variabel dengan kejadian ulkus DM ditemukan 3 variabel yang memiliki nilai signifikan dengan ketentuan $\mathrm{p}$ value $\leq 0.05$. variabel yang memiliki nilai signifikan memiliki arti bahwa ada hubungan keterkaitan antara independen dan dependen dan sebaliknya untuk nilai yang tidak signifikan.

\section{DISCUSSION}

\section{Hubungan Kadar Gula Darah dengan Kejadian Ulkus Diabetikum}

Hasil penelitian menunjukkan bahwa terdapat hubungan antara kadar glukosa darah dengan ulkus kaki diabetik dan didapatkan hasilnya responden dengan resiko tinggi terjadinya ulkus kaki diabetik yaitu kadar glukosa darah $\geq 200 \mathrm{mg} / \mathrm{dl}$ memiliki derajat ulkus kaki diabetik 1 dan derajat ulkus kaki diabetik 2. penelitian ini selaras dengan penelitian Maidiana,dkk (2012) dan Siti (2009) yang menyatakan bahwa ada hubungan antara kadar HbA1C dengan kejadian ulkus kaki diabetik pada pasien.

Hal ini menunjukan bahwa kadar glukosa darah yang tinggi dapat menyebabkan penurunan kemampuan pembuluh darah dalam berkontraksi maupun relaksasi sehingga perfusi jaringan bagian distal dari tungkai kurang baik dan juga kadar

Tabel 2 Tabulasi Silang antara Data Demografi Responden dengan Kejadian Ulkus DM ( $\mathrm{n}=115$ )

\begin{tabular}{|c|c|c|c|c|c|c|}
\hline \multirow{3}{*}{$\begin{array}{c}\text { Karakteristik Demografi } \\
\text { Responden }\end{array}$} & \multirow{3}{*}{ Kategori } & \multicolumn{4}{|c|}{ Kejadian Ulkus DM } & \multirow{3}{*}{$\Sigma$} \\
\hline & & \multicolumn{2}{|c|}{ Tidak } & \multicolumn{2}{|c|}{ Ya } & \\
\hline & & $\mathbf{n}$ & $\%$ & n & $\%$ & \\
\hline \multirow{3}{*}{ Usia } & 26-35 Tahun & 8 & 80 & 2 & 20 & 10 \\
\hline & 36-45 Tahun & 24 & 68 & 11 & 32 & 35 \\
\hline & $>45$ Tahun & 49 & 70 & 21 & 30 & 70 \\
\hline & Laki-laki & 31 & 71 & 13 & 29 & 44 \\
\hline Jenis Kelamin & Perempuan & 50 & 71 & 21 & 29 & 71 \\
\hline & Pendidikan Dasar & 9 & 53 & 8 & 47 & 17 \\
\hline \multirow[t]{2}{*}{ Pendidikan } & Pendidikan Menengah & 54 & 76 & 17 & 24 & 71 \\
\hline & Pendidikan Tinggi & 18 & 66 & 9 & 34 & 27 \\
\hline
\end{tabular}

Tabel 3 Tabulasi Silang Antara Variable Yang Diukur Dengan Kejadian Ulkus DM (n=115)

\begin{tabular}{|c|c|c|c|c|c|c|}
\hline \multirow{3}{*}{$\begin{array}{c}\text { Karakteristik Demografi } \\
\text { Responden }\end{array}$} & \multirow{3}{*}{ Kategori } & \multicolumn{4}{|c|}{ Kejadian Ulkus DM } & \multirow{3}{*}{$\Sigma$} \\
\hline & & \multicolumn{2}{|c|}{ Tidak } & \multicolumn{2}{|c|}{ Ya } & \\
\hline & & $\mathbf{n}$ & $\%$ & $\mathbf{n}$ & $\%$ & \\
\hline \multirow{3}{*}{ Tingkat Stress } & Tinggi & 70 & 75 & 23 & 25 & 93 \\
\hline & Sedang & 2 & 18 & 9 & 82 & 11 \\
\hline & Rendah & 9 & 82 & 2 & 18 & 11 \\
\hline \multirow{2}{*}{ Kadar gula darah } & $<200$ & 69 & 76 & 22 & 24 & 91 \\
\hline & $>200$ & 12 & 50 & 12 & 50 & 24 \\
\hline \multirow{2}{*}{ Perawatan kaki } & Buruk & 80 & 74 & 29 & 26 & 109 \\
\hline & Baik & 1 & 16 & 5 & 84 & 6 \\
\hline
\end{tabular}


glukosa darah yang tinggi merupakan lingkungan yang subur untuk berkembang biaknya kuman patogen yang bersifat anaerob karena plasma darah penderita diabetes mellitus yang tidak terkontrol dan memiliki viskositas yang tinggi Keadaan inilah yang mengembangkan terjadinya ulkus kaki diabetik pada penderita mellitus yang memiliki kadar glukosa darah yang tinggi (Smeltzer, 2015).

Faktor lain yang dapat mempengaruhi keadaan ini adalah usia responden yang lansia telah mengalami penurunan sistem organ tubuh sehingga rentan mengalami komplikasi, lama menderita diabetes > 10 tahun karena kadar glukosa darah yang tidak terkendali pada penderita diabetes $>10$ tahun akan menimbulkan berbagai komplikasi, lama luka yang tidak di rawat secara tepat sehingga luka tidak sembuh-sembuh dalam 7-24 hari karena telah terjadi kegagalan proses angiogenesis, jenis kelamin perempuan dapat mempengaruhi perkembangan derajat ulkus kaki dan kadar glukosa darah responden karena perubahan hormonal, kepatuhan diet yang tidak teratur akan, mengkonsumsi obat yang tidak rutin, mengontrol kadar gula darah, stress, kebiasaan merokok dan olahraga yang kurang dilakukan oleh responden sehingga dapat mempengaruhi kadar glukosa darah responden.

Pada penelitian ini tidak ditemukannya penderita diabetes mellitus yang memiliki derajat ulkus kaki diabetik 0, 4 dan 5. Hal ini dapat disebabkan oleh lama luka yang dialami penderita diabetes mellitus masih dalam fase inflamasi, fase destruktif dan fase proliferatif telah mendapatkan pertolongan perawatan ulkus kaki diabetik sehingga dapat mencapai fase maturasi atau penyembuhan dengan baik. Jika penderita diabetes mellitus yang memiliki ulkus kaki diabetik tidak segera mendapatkan perawatan kaki maka luka akan sulit sembuh.Hasil penelitian ini dapat disimpulkan semakin tinggi kadar glukosa darah penderita diabetes mellitus, semakin tinggi pula derajat ulkus kaki diabetik yang dialami. Jika penderita diabetes mellitus dengan derajat ulkus kaki diabetik yang tinggi, maka penderita diabetes mellitus tersebut akan memiliki kadar glukosa darah yang tinggi pula.

\section{Hubungan Perawatan Kaki dengan Kejadian Ulkus Diabetikum}

Hasil penelitian menunjukkan bahwa ada hubungan antara perawatan kaki dengan kejadian ulkus DM. Hal ini sesuai dengan penelitian Viscogliosi et al.,(2018) yang menyatakan bahwa perawatan kaki berhubungan dengan kejadian ulkus DM. responden dengan perawatan kaki yang buruk berisiko 3.5 kali lebih rentan terkena ulkus DM. Hal ini menguatkan pernyataan bahwa ketika seseorang didiagnosa menderita diabetes, perawatan kaki yang tepat menjadi sangat penting. Kemampuan perawatan kaki yang baik mampu dilakukan oleh orang dewa, dimana usia dewasa menurut WHO International $>18$ tahun.

Tabel 4 Hasil Uji Variabel yang Diukur

\begin{tabular}{|c|c|c|c|c|c|c|c|c|c|}
\hline \multirow{2}{*}{ Variabel } & \multirow{2}{*}{ Parameter } & \multirow{2}{*}{ Min } & \multirow{2}{*}{ Max } & \multirow{2}{*}{ Mean } & \multirow{2}{*}{ SD } & \multicolumn{2}{|c|}{ CI 95\% } & \multirow{2}{*}{$\begin{array}{c}P \\
\text { value }\end{array}$} & \multirow{2}{*}{$\begin{array}{l}\text { Coeficient } \\
\text { corelation }\end{array}$} \\
\hline & & & & & & Lower & Upper & & \\
\hline Perawatan & Perawatan kaki & 1 & 15 & 10.41 & 2.517 & 9.94 & 10.88 & \multirow{4}{*}{0.003} & \multirow{4}{*}{0.276} \\
\hline \multirow[t]{3}{*}{ Kaki } & Pemakaian alas kaki & 1 & 18 & 12.40 & 3.709 & 11.71 & 13.09 & & \\
\hline & Menggunting kuku & 0 & 3 & 2.40 & 0.912 & 2.23 & 2.57 & & \\
\hline & $\begin{array}{l}\text { Memberikan pelembab } \\
\text { pada kaki }\end{array}$ & 0 & 3 & 2.12 & 0.832 & 1.96 & 2.27 & & \\
\hline \multirow[t]{4}{*}{ Tingkat stress } & Beban Emosi & 16 & 30 & 24.92 & 2.644 & 24.42 & 25.40 & \multirow{4}{*}{0.049} & \multirow{4}{*}{0.230} \\
\hline & Distress terkait dengan & 13 & 24 & 19.96 & 2.944 & 19.41 & 20.50 & & \\
\hline & $\begin{array}{l}\text { Tenaga Kesehatan } \\
\text { Distress terkait dengan } \\
\text { perawatan/penanganan }\end{array}$ & 13 & 30 & 24.79 & 4.052 & 24.03 & 25.54 & & \\
\hline & Distress Interpersonal & 6 & 18 & 15.37 & 2.206 & 14.96 & 15.78 & & \\
\hline \multirow{2}{*}{$\begin{array}{l}\text { Kadar gula } \\
\text { darah }\end{array}$} & $<200$ & 140 & 198 & 172.32 & 7.932 & 163.11 & 174.41 & \multirow{2}{*}{0.013} & \multirow{2}{*}{0.184} \\
\hline & $>200$ & 204 & 474 & 302.16 & 8.991 & 203.17 & 481.01 & & \\
\hline
\end{tabular}


Perawatan kaki yang buruk pada diabetisi akan mengakibatkan masalah kesehatan yang serius, di antaranya amputasi kaki. American Diabetes Association merekomendasikan pemeriksaan kaki tahunan oleh tenaga kesehatan dan pemeriksaan kaki harian oleh diabetisi atau keluarganya. Tindakan awal ini bisa mencegah dan mengurangi sebesar 50\% dari seluruh amputasi yang disebabkan diabetes (Rowland, 2009). Black dan Hawks (2009) menjelaskan edukasi yang tepat mengenai perawatan kaki, dan penanganan awal diharapkan mampu mencegah infeksi kaki.

Perawatan kaki yang efektif mampu memutus risiko ulkus menjadi amputasi. Lebih lanjut, Black dan Hawks (2009) menjelaskan bahwa perawat bertanggung jawab dalam pengelolaan diabetisi, meliputi pengkajian diabetes, pendidikan dan perawatan langsung. Evaluasi terhadap pengetahuan, kemampuan perawatan diri, status fisik dan kebutuhan klien bisa dilakukan di awal kontak dengan klien.Dewi, (2006) pernah meneliti tentang hubungan aspek perawatan kaki dengan kejadian ulkus kaki diabetes di RS PKU Muhammadiyah Yogyakarta, dan didapatkan hasil yang bermakna ( $p=0,02-0,03)$.Hal ini sangat sesuai dan mendukung hasil penelitian yang dilakukan oleh peneliti. Oleh sebab itu, perawat sangat dianjurkan untuk mengajarkan diabetisi tentang perawatan kaki yang baik, sesuai dengan teori nursing system Orem melalui supportive compensatory. Perawat diharapkan mampu memandu, mengarahkan, dan mengajarkan tentang perawatan kaki yang baik bagi diabetisi. Hal ini diharapkan bahwa diabetisi akan memahami dan melakukan perawatan kaki mandiri dengan baik yang didukung oleh keluarganya.

May (2008) menyebutkan perawatan kaki mandiri yang harus diajarkan pada diabetisi meliputi : 1) Mencuci kaki secara rutin setiap hari dan mengeringkan seluruh permukaan kaki terutama di sela jari,2) Menggunakan pelembab (lotion) secara rutin untuk mencegah kaki menjadi kering dan pecahpecah, 3) Memotong kuku dengan hatihati, dengan cara memotong kuku dengan lurus dan tidak memotong sudut kuku,4) Menggunakan purnice untuk membuang kalus. Hal-hal ini jika dilakukan dengan baik akan sangat mendukung untuk pencegahan risiko ulkus kaki diabetes.

\section{Hubungan Stress dengan Kejadian Ulkus Diabetikum}

Hasil penelitian menunjukkan stres merupakan faktor yang berhubungan dengan terjadinya komplikasi ulkus. Sejalan dengan hasil penelitian yang dilakukan oleh Vedrhara et al. (2010) mengemukakan stres pada penderita Diabetes Mellitus dapat berakibat ketidakmampuan dalam pengontrolan kadar gula darah. Pada keadaan stres akan terjadi peningkatan hormone katekolamin, glukagon, glubbkokortikoid, B-endrotopin dan hormone pertumbuhan. Selanjutnya kortisol juga akan berdampak terhadap penurunan daya tahan tubuh penderita DM tipe 2, sehingga akan mudah untuk mengalami permasalahan kesehatan.

Menurut Lazarus dan Folkman (dalam Indri, 2007) stres adalah keadaan internal yang dapat diakibatkan oleh tuntunan fisik dari tubuh (kondisi penyakit, latihan, dll) atau oleh kondisi lingkungan dan sosial yang dinilai potensial membahayakan, tidak terkendali atau melebihi kemampuan individu untuk melakukan koping. Stres diawali dengan reaksi waspada (alarm reaction) terhadap adanya ancaman yang ditandai oleh proses tubuh secara otomatis seperti meningkatnya denyut jantung, yang kemudian diikuti dengan reaksi penolakan terhadap stressor dan akan mencapai tahap kehabisan tenaga (exhaustion) jika individu merasa tidak mampu untuk bertahan.

Stres berhubungan dengan penurunan kemampuan individu dalam melakukan perawatan dirinya. Pasien yang mengalami stres, memiliki motivasi dan manajemen diri yang rendah sehingga kemampuan dalam mengontrol gula darah kurang ( $\mathrm{Wu}, 2011$ ) Penelitian ini juga didukung 
oleh(Beardsley \& Goldstein 2003) mereview

literatur tentang hubungan antara stres, regulasi gula darah dan gaya koping, menyimpulkan bahwa tingginya tingkat stres dihubungkan dengan buruknya regulasi gula darah. Akibat buruknya regulasi gula darah atau kontrol DM yang buruk dapat mengakibatkan hiperglikemia dalam jangka panjang yang memicubeberapa komplikasi yang serius baik makrovaskuler maupun mikrovaskuler seperti penyakit jantung, penyakit vaskuler perifer, gagal jantung, kerusakan saraf dan kebutaan. Banyaknya komplikasi yang menyertai penyakit DM telah memberikan kontribusi terjadinya perubahan fisik, psikologis dan sosial. Salah satu perubahan psikologis yang paling sering adalah stres dan depresi.

\section{CONCLUSION}

Secara keseluruhan variabel memiliki hubungan yang positif. Perawatan kaki yang baik akan menurunkan risiko kejadian ulkus DM. Tingkat stress dan kadar gula darah yang tinggi akan meningkatkan risiko ulkus DM. Faktor host dapat mempengaruhi kejadian ulkus DM sehingga diperlukan intervensi yang dapat memperbaiki perilaku perawatan kaki, pengendalian gula darah dan manajemen stress.

\section{REFERENCE}

Ahmad, J. (2016). The diabetic foot. Diabetes and Metabolic Syndrome: Clinical Research and Reviews, 10(1), 48-60. https://doi.org/10.1016/j.dsx.2015.04.002

Alaei Karahroudi, F., Mohammadi Shahbolaghi, F., Hosseini, M. A., \& M, R. (2016). Experiences of selfmanagement of type I diabetes in adolescents: A phenomenological study. Iranian Journal of Endocrinology and Metabolism, 17(6), 1-11.

Alavi, A., Sibbald, R. G., Mayer, D., Goodman, L., Botros, M., Armstrong, D. G., ... Kirsner, R. S. (2014). Diabetic foot ulcers: Part I. Pathophysiology and prevention. Journal of the American Academy of Dermatology, 70(1), 1.e1-1.e18. https://doi.org/10.1016/j.jaad.2013.06.055

Amoah, V. M. K., Anokye, R., Acheampong, E., Dadson, H. R., Osei, M., \& Nadutey, A. (2018). The experiences of people with diabetes-related lower limb amputation at the Komfo Anokye Teaching Hospital (KATH) in Ghana. BMC Research Notes, 11(1), 1-5. https://doi.org/10.1186/s1310401s8-3176-1
Articlesbase, (2009). Hypoglycemia in type 2 diabetes: Pathophysiology, frequency, and effects of different treatment modalities. Diabetes care, 28(12), 2948-2961.

Badan Penelitian dan Pengembangan Kesehatan. (2018). Riset Kesehatan Dasar (RISKESDAS) 2013. Laporan Nasional 2013, 1-384. https://doi.org/1 Desember 2013

Badriah, S., \& Sahar, J. (2018). Family support in caring for older people with diabetes mellitus: a phenomenology study. Enfermeria Clinica, 28, 245-249. https://doi.org/10.1016/S11308621(18)30077-9

Brod, M., Pohlman, B., Blum, S. I., Ramasamy, A., \& Carson, R. (2015). Burden of Illness of Diabetic Peripheral Neuropathic Pain: A Qualitative Study. Patient, 8(4), 339-348. https://doi.org/10.1007/s40271-014-0093-9

Bustan, M. N. (2016). Epidemiologi Penyakit Tidak Menular. Jakarta: Rineka Cipta.

Bai, J., Lovblom, L. E., Cardinez, M., Weisman, A., Farooqi, M. A., Halpern, E. M., ... Perkins, B. A. (2017). Journal of Diabetes and Its Complications Neuropathy and presence of emotional distress and depression in longstanding diabetes : Results from the Canadian study of longevity in type 1 diabetes. Journal of Diabetes and Its Complications, 31(8), 1318-1324. https://doi.org/10.1016/j.jdiacomp.2017.05.002

Bennett, J. (2016). Limb loss: The unspoken psychological aspect. Journal of Vascular Nursing, $34(4)$, 128-130. https://doi.org/10.1016/j.jvn.2016.06.001

Chithambo, T., \& Forbes, A. (2015). Exploring factors that contribute to delay in seeking help with diabetes related foot problems: a preliminary qualitative study using Interpretative Phenomenological Analysis. International Diabetes Nursing, 12(1), 20-26. https://doi.org/10.1179/2057331615Z.0000000 006

De Almeida, S. A., Salomé, G. M., Dutra, R. A. A., \& Ferreira, L. M. (2014). Feelings of powerlessness in individuals with either venous or diabetic foot ulcers. Journal of Tissue Viability, 23(3), 109-114. https://doi.org/10.1016/j.jtv.2014.04.005

Delea, S., Buckley, C., Hanrahan, A., McGreal, G., Desmond, D., \& McHugh, S. (2015). Management of diabetic foot disease and amputation in the Irish health system: A qualitative study of patients' attitudes and experiences with health services. BMC Health Services Research, 15(1), 1-10. https://doi.org/10.1186/s12913-015-0926-9

Dros, A. D., Cull, C. A., Macleod, K. M., \& Holman, R. R. (2006). Hypoglycemia in Type 2 diabetic patients randomized to and maintained on monotherapy with diet, sulfonylurea, metformin, or insulin for 6 years from diagnosis: UKPDS73. Journal of diabetes and its complications, 20(6), 395-401.

Foster, D., \& Lauver, L. S. (2014). When a diabetic foot ulcer results in amputation: A qualitative study of 
the lived experience of 15 patients. Ostomy Wound Management, 60(11), 16-22.

Elisabeth, K., Clench, J., \& Kjærsti, R. (2016). Journal of Diabetes and Its Complications Sense of mastery as mediator buffering psychological distress among people with diabetes, 30, 839-844. https://doi.org/10.1016/j.jdiacomp.2016.03.022

Eason, L., Cox, D., Kovatchev, B., Julian, D., \& Clarke, W. (2005). The psychosocial impact of severe hypoglycemic episodes on spouses of patients with IDDM. Diabetes Care, 20(10), 1543-1546.

Fearns, N., Heller-murphy, S., Kelly, J., \& Harbour, J. (2017). Placing the patient at the centre of chronic wound care: A qualitative evidence synthesis. Journal of Tissue Viability, 26(4), 254-259. https://doi.org/10.1016/j.jtv.2017.09.002

Frygberk, S., Gojka, R., Green, A., Sicree, R., \& King, H. (2006). Global Prevalence of diabetes: Estimates for the year 2000 and projections for 2030. Diabetes care, 27(5), 1047-1053.

Gorecki, C., Nixon, J., Lamping, D. L., Alavi, Y., \& Brown, J. M. (2014). International Journal of Nursing Studies Patient-reported outcome measures for chronic wounds with particular reference to pressure ulcer research: A systematic review. International Journal of Nursing Studies, 51(1), 157-165.

https://doi.org/10.1016/j.ijnurstu.2013.03.004

Guell, C., \& Unwin, N. (2015). Barriers to diabetic foot care in a developing country with a high incidence of diabetes related amputations: An exploratory qualitative interview study. BMC Health Services Research, 15(1), 1-7. https://doi.org/10.1186/s12913-015-1043-5

Guo, K., Zhang, L., Zhao, F., Lu, J., Pan, P., Yu, H., ... Jia, W. (2016). Journal of Diabetes and Its Complications Prevalence of chronic kidney disease and associated factors in Chinese individuals with type 2 diabetes : Cross-sectional study. Journal of Diabetes and Its Complications, 30(5),

803-810. https://doi.org/10.1016/j.jdiacomp.2016.03.020

Heitzman Kirkman, M., Briscoe, V. J., Clark, N., Florez, H., Haas, L. B., Halter, J. B., . . . Swift, C. S. (2010). Diabetes in older adults: A consensus report. journal of the american geriatrics society, 60(12), 2342-2356. doi: 10.1111/jgs.12035

Huang, C., Ph, D., Hsieh, H., Ph, D., Chiu, H., \& Ph, D. (2017). Original Research Report Impact of Anxiety Disorders on Mortality for Persons With Diabetes: A National Population-Based Cohort Study. Psychosomatics, 58(3), 266-273. https://doi.org/10.1016/j.psym.2016.11.009

Joensen, L. E., Willaing, I., Holt, R. I. G., Wens, J., Skovlund, S., \& Peyrot, M. (2017). Journal of Diabetes and Its Complications Household composition and psychological health : Results of the Second Diabetes Attitudes, Wishes and Needs ( DAWN2 ) study. Journal of Diabetes and Its Complications, 31(2), 340-346. https://doi.org/10.1016/j.jdiacomp.2016.07.006
Johansson, K., ÖSterberg, S. A., Leksell, J., \& Berglund, M. (2016). Patients' experiences of support for learning to live with diabetes to promote health and well-being: A lifeworld phenomenological study. International Journal of Qualitative Studies on Health and Well-Being, 11(June 2017). https://doi.org/10.3402/qhw.v11.31330

Kemenkes RI. (2014). Situasi dan Analisis Diabetes. Pusat Data Dan Informasi Kementerian Kesehatan RI. https://doi.org/24427659

Kolltveit, B.-C. H., Gjengedal, E., Graue, M., Iversen, M. M., Thorne, S., \& Kirkevold, M. (2016). Telemedicine in diabetes foot care delivery: health care professionals' experience. BMC Health Services Research, 16(1), 134. https://doi.org/10.1186/s12913-016-1377-7

Kolltveit, B. C. H., Gjengedal, E., Graue, M., Iversen, M. M., Thorne, S., \& Kirkevold, M. (2017). Conditions for success in introducing telemedicine in diabetes foot care: A qualitative inquiry. BMC Nursing, 16(1), 1-10. https://doi.org/10.1186/s12912017-0201-y

Lee, P. A., Greenfield, G., \& Pappas, Y. (2018). Patients' perception of using telehealth for type 2 diabetes management: A phenomenological study. $B M C$ Health Services Research, 18(1), 1-9. https://doi.org/10.1186/s12913-018-3353-x

LeMone, D. A., Havlin, C. E., Craft, S., \& Cryer, P. (2011). Mechanism of awareness of hypoglycemia. Perception of neurogenic (predominantly cholinergic) rather than neuroglycopenic symptoms. Diabetes, 42(12), 1791-1798.

Lim, J. Z. M., Ng, N. S. L., \& Thomas, C. (2017). Prevention and treatment of diabetic foot ulcers. Journal of the Royal Society of Medicine, 110(3), 104-109. https://doi.org/10.1177/0141076816688346

Liu, J., Hu, K., Su, H., Xu, B., Xu, J., \& Zhou, J. (2017). Classification Of Diabetic Feet In Terms Of Risk Of Ulceration Classification Of Diabetic Feet In Terms Of Risk Of Ulceration Classification Of Diabetic Feet In Terms Of Risk Of Ulceration Diabetic feet refers to the lower limb of diabetic patients and it, 17, 129-134.

Maidiana.,R.E.,Tety.,U.,\& Paul.,T.(2012). Analisis faktor yang berhubungan dengan kejadian ulkus DM di wilayah kerja Puskesmas Semarang. Repository UGM. Tidak di publikasikan.

Manda, C. D., Phillips, L. S., Ziemer, D. C., Gallina, D. L., \& et al. (2012). Hypoglycemia in patients with type 2 diabetes mellitus. Archives of internal medicine, 161(13), 1653-1659.

Margareth, M. C. R. (2012). Asuhan Keperawatan Medikal Bedah dan Penyakit Dalam. Yogyakarta: Nuha Medika.

Mckechnie, P. S., \& John, A. (2014). Anxiety and depression following traumatic limb amputation: A systematic review. Injury, 45(12), 1859-1866. https://doi.org/10.1016/j.injury.2014.09.015

Naicker, K., Øverland, S., Johnson, A., Manuel, D., \& Skogen, J. C. (2017). Psychoneuroendocrinology Symptoms of anxiety and depression in type 2 
diabetes: Associations with clinical diabetes measures and self-management outcomes in the Norwegian HUNT study, 84(July), 116-123. https://doi.org/10.1016/j.psyneuen.2017.07.002

Ness, G. P., Wang, J., Broomhall, J., \& Kelly, P. (2003). Frequency of severe hypoglycemia requiring emergency treatment in type 1 and type 2 diabetes: A population-based study of health service resource use. Diabetes care, 26(4), 11761180.

Nikoloudi, M., Eleftheriadou, I., Tentolouris, A., Kosta, O. A., \& Tentolouris, N. (2018). Diabetic Foot Infections: Update on Management. Current Infectious Disease Reports, 20(10). https://doi.org/10.1007/s11908-018-0645-6

Norman, D.G.Eikelboorn,R.T.,Hankey.,O.P (2004). The Experience of Hypoglycaemia and Strategies Used For Its Management by Community-Dwelling Adults with Diabetes Mellitus: A Systematic Review. International Journal of Evidence Based Healthcare, 10(3), 169-180.

Noor, S., Zubair, M., \& Ahmad, J. (2015). Diabetic foot ulcer - A review on pathophysiology, classification and microbial etiology. Diabetes and Metabolic Syndrome: Clinical Research and Reviews, 9(3), 192-199. https://doi.org/10.1016/j.dsx.2015.04.007

Nurrahmani, H. K. (2015). Stop Diabetes, Hipertensi, Kolesterol Tinggi, Jantung Koroner. Yogyakarta: Istana Media.

Nyamu, S.-H., Lin, Y.-Y., Hsu, C.-W., Cheng, C.-S., \& Chu, D.-M. (2003). Hypoglycemia revisited in the acute care setting. Yonsei medical journal, 52(6), 898908. doi: 10.3349/ymj.2011.52.6.898

Ota, A., \& Ulrih, N. P. (2017). An Overview of Herbal Products and Secondary Metabolites Used for Management of Type Two Diabetes. Frontiers in Pharmacology, 8(July), 1-14. https://doi.org/10.3389/fphar.2017.00436

Pastor, A., O’Brien, C. L., Teng, J., Conn, J., Loh, M., Collins, L., ... Bonomo, Y. (2018). Experiences of young adults with type 1 diabetes while using alcohol and recreational drugs: An interpretative phenomenological analysis (IPA) of semistructured interviews. Diabetes Research and Clinical Practice, 141, 47-55. https://doi.org/10.1016/j.diabres.2018.04.029

Paton, J. S., Roberts, A., Bruce, G. K., \& Marsden, J. (2014). Patients' Experience of therapeutic footwear whilst living at risk of neuropathic diabetic foot ulceration: An interpretative phenomenological analysis (IPA). Journal of Foot and Ankle Research, 7(1), 1-9. https://doi.org/10.1186/1757-1146-7-16

Pedras, S., Carvalho, R., \& Pereira, M. G. (2016). Predictors of quality of life in patients with diabetic foot ulcer: The role of anxiety, depression, and functionality. Journal of Health Psychology, 135910531665676. https://doi.org/10.1177/1359105316656769

Perkeni. (2015). Pengelolaan dan pencegahan diabetes melitus tipe 2 di indonesia 2015. Pengurus
Besar Perkumpulan Endokrinologi Indonesia (PB Perkeni).

https://doi.org/10.1017/CBO9781107415324.0 04

Peters., S, Acharya LD, Rao PGM, (2007) Knowledge, attitude, and practice outcome: Evaluating the impact of counseling in hospitalized diabetic patient in india. P\&T Around the World, Page; 31 (7), $383-395$.

Peyrot, M., Kovacs, K., Davies, M., Forbes, A., Hermanns, N., Holt, R., ... Skovlund, S. E. (2012). Diabetes Attitudes Wishes and Needs 2 ( DAWN2 ): A multinational, multi-stakeholder study of psychosocial issues in diabetes and personcentred diabetes care. Diabetes Research and Clinical Practice, 99(2), 174-184. https://doi.org/10.1016/j.diabres.2012.11.016

Reiber, M., Briscoe, V. J., Clark, N., Florez, H., Haas, L. B., Halter, J. B., . . Swift, C. S. (2000). Diabetes in older adults: A consensus report. journal of the american geriatrics society, 60(12), 2342-2356. doi: 10.1111/jgs.12035

Sieggreen, M., \& Berger, W. (1999). Higher incidence of severe hypoglycaemia leading to hospital admission in type 2 diabetic patients treated with long-acting versus short-acting sulphonylureas. Diabetic medicine, 16(7), 586-590. doi: 10.1046/j.1464-5491.1999.00110.x

Stuckey, H. L., Mullan-jensen, C., Kalra, S., Reading, J., Wens, J., Vallis, M., ... Peyrot, M. (2016). Living with an adult who has diabetes: Qualitative insights from the second Diabetes Attitudes, Wishes and Needs ( DAWN2 ) study. Diabetes Research and Clinical Practice, 116, 270-278. https://doi.org/10.1016/j.diabres.2016.04.028

Razjouyan, J., Grewal, G. S., Talal, T. K., Armstrong, D. G., Mills, J. L., \& Najafi, B. (2017). Does Physiological Stress Slow Down Wound Healing in Patients with Diabetes? Journal of Diabetes Science and Technology, 11(4), 685-692. https://doi.org/10.1177/1932296817705397

Shanty, M. (2011). Silent Killer Disease. Yogyakarta: Javalitera.

Siersma, V., Thorsen, H., Holstein, P. E., Kars, M., Apelqvist, J., Jude, E. B., ... Schaper, N. C. (2017). Diabetic complications do not hamper improvement of health-related quality of life over the course of treatment of diabetic foot ulcers the Eurodiale study. Journal of Diabetes and Its Complications, 31(7), 1145-1151. https://doi.org/10.1016/j.jdiacomp.2017.04.008

Syafril, S. (2018). Pathophysiology diabetic foot ulcer. IOP Conf. Ser.: Earth Environ. Sci, 125, 12161. https://doi.org/10.1088/17551315/125/1/012161

Udovichenko, O. V, N.V., M., M.V., A., O.A., Y., \& E.G., B. E. A. and S. (2017). Prevalence and Prognostic Value of Depression and Anxiety in Patients with Diabetic Foot Ulcers and Possibilities of their Treatment. Current Diabetes Reviews.https://doi.org/http://dx.doi.org/10.217 4/1573399812666160523143354 
Vileikyte, L., Crews, R. T., \& Reeves, N. D. (2017). Psychological and Biomechanical Aspects of Patient Adaptation to Diabetic Neuropathy and Foot Ulceration. Current Diabetes Reports, 17(11). https://doi.org/10.1007/s11892-017-0945-5

Vlachakis, C., Dragoumani, K., Raftopoulou, S., Mantaiou, M., Papageorgiou, L., Tsaniras, S. C., ... Vlachakis, D. (2018). Human emotions on the onset of cardiovascular and small vessel related diseases. In Vivo, 32(4), 859-870. https://doi.org/10.21873/invivo.11320
Washington, E. D., \& Williams, A. E. (2016). An exploratory phenomenological study exploring the experiences of people with systemic disease who have undergone lower limb amputation and its impact on their psychological well-being. Prosthetics and Orthotics International, 40(1), 4450.

https://doi.org/10.1177/0309364614556838

WHO. (2014). Global status report on noncommunicable diseases 2014. World Health, 176. https://doi.org/ISBN 9789241564854. 